\title{
Surfaces
}

\section{THE CONTEMPORARY AND THE POSTHUMOUS}

\section{Ernst Behler}

Volume 4, 1994

CONFÉRENCE INTERNATIONALE SUR LE DISCOURS HUMANISTE

(PREMIÈRE RENCONTRE, 3-8 AVRIL, 1994)

INTERNATIONAL CONFERENCE ON HUMANISTIC DISCOURSE (FIRST

MEETING, APRIL 3-8, 1994)

URI : https://id.erudit.org/iderudit/1064967ar

DOI : https://doi.org/10.7202/1064967ar

Aller au sommaire du numéro

Éditeur(s)

Les Presses de l’Université de Montréal

ISSN

1188-2492 (imprimé)

1200-5320 (numérique)

Découvrir la revue

Citer cet article

Behler, E. (1994). THE CONTEMPORARY AND THE POSTHUMOUS. Surfaces, 4. https://doi.org/10.7202/1064967ar
Résumé de l'article

Abordées dans toute leur complexité, les notions de culture et d'humanisme ne peuvent être ramenées à une signification unique et entrent en fait souvent en conflit l'une avec l'autre. C'est ce que montre l'auteur, en examinant ces notions dans une perspective historique qui fait voir les diverses élaborations qu'elles ont connu en Allemagne depuis l'époque romantique. Novalis, les frères Schlegel et Nietzsche servent, parmi d'autres, à dégager une réflexion théorique sur la pertinence des notions de culture et d'humanisme pour la critique contemporaine. 


\title{
THE CONTEMPORARY AND THE POSTHUMOUS
}

\author{
Ernst Behler
}

\begin{abstract}
Culture humanism are problematic notions that cannot be reduced to a singular meaning and that are often in conflict with one another. This essay examines these notions historically, in early German Romanticism and Nietzsche, with discussions of Novalis and the Schlegels, among others, and concludes with theoretical reflections on these themes and their contemporary significance.
\end{abstract}

\section{RÉSUMÉ}

Abordées dans toute leur complexité, les notions de culture et d'humanisme ne peuvent être ramenées à une signification unique et entrent en fait souvent en conflit l'une avec l'autre. C'est ce que montre l'auteur, en examinant ces notions dans une perspective historique qui fait voir les diverses élaborations qu'elles ont connu en Allemagne depuis l'époque romantique. Novalis, les frères Schlegel et Nietzsche servent, parmi d'autres, à dégager une réflexion théorique sur la pertinence des notions de culture et d'humanisme pour la critique contemporaine.

1. Why is it that questions about the nature and function of humanistic discourse and the spaces between a culture and between cultures arouse discomfort and uneasiness in the one who is asked to answer them? Such questions obviously create something of an examination atmosphere when the task is to assemble the largest possible amount of material in the briefest possible space and to do all this in response to weighty problems. This situation is certainly aggravated in our case when humanistic discourse means something different in all three Western languages represented by 
our group and when the prevailing North American concept of the humanities in its demarcation from the social sciences and the natural sciences is not germane to either Geisteswissenschaften or sciences humaines. These concepts also often enjoy temporary national favor and fashion that make them different in various national contexts. This is definitely the case in the present North American usage of 'culture' and 'cultural studies' which often privilege culture as the bedrock and matrix of everything. The first cultural historian, Voltaire, did not use the term culture, preferring siècle; and the cultural historian who did use the term, Burckhardt, emphasized individualism and sheer force of character, an emphasis quite different from today's cultural studies. Such variations and nuances in the usage of terms will certainly increase when the discussion moves on to the spaces between Western and Eastern discourses and cultures, but already signal vigilance when the subject is limited to only Western traditions. Yet, above all, our uneasiness about such definitions and positions takes its origin from the distinct awareness that once one has agreed to becoming engaged in this game on a merely nominalistic basis, for definition's sake only, one is soon drawn into questions as to the priority of discourse over culture and culture over discourse, i.e., into questions nobody will be able to answer. At the root of all this discomfort lies of course a basic skepticism towards conceptualization and the self-congratulatory satisfaction with mere conceptual solutions. Heidegger signaled some of these reservations about a result-oriented type of thinking in the service of doing and making when, in his Letter on Humanism, he described the degradation of the great humanisms of the West -- in Antiquity, the Middle Ages, the Renaissance, the age of Goethe, and of Nietzsche -- to an instrument of education, a classroom matter, a cultural concern, culture politics, and culture industry. At the same time, it is easily understandable that an International Center for Humanistic Discourse requests a commitment, even an investment, on the part of its members with regard to these terms. To diminish as much as possible the risk of my own commitments, I will choose the option of talking about the issues first historically, from my expertise -- if I may say so, mostly in Early Romanticism and Nietzsche - -- and of engaging subsequently in some theoretical reflections on these themes. My particular focus on spaces between discourses and between cultures will be that of the contemporary and the posthumous.

2. Humanistic discourses probably function best in their cultural context when they intervene -- in the sense specified in the first question of the last memorandum --- even critically and confrontationally, by challenging an entire set of established cultural habits, values, beliefs, and norms. Good historical examples of this type of functioning are the early period of the Italian Renaissance (Dante, Petrarch, Boccaccio) and early German Romanticism (the Schlegels, Novalis, Tieck), which describe moments in modern Western history when new humanistic discourses in literature and the arts challenged and eventually replaced the established rules and norms in that arena. In the case of Early Romanticism, the emergence of its critical discourse quickly led to a basic revision of the literary canon of that time and also to a new model for the understanding of the creative process. The main target was the classicist doctrine and its tenets. The dominant classicist canon was split open, and authors such as Aristophanes, the 
troubadours, Dante, Cervantes, even Shakespeare, and Calderón gained prominence. The classicist view of literature as representing or imitating a pregiven reality (nature as it surrounds us, the great events of history, the figures and fables of classical mythology, the events of Christianity, or simply the great works of the past) was exchanged for conceptions such as creative imagination, symbol, myth, and type. These changes in the literary and critical realm did not leave the other spheres of artistic and cultural life untouched but provoked an "animated interaction" ("lebendige Wechselwirkung") with them. Of special importance are painting and music, which on the grounds of non-mimetic artistic creation came to occupy, along with poetry, privileged positions, and of particular interest in this context is the Romantic theory and practice of landscape painting. The decisive step in the departure from the neoclassicist theory of painting can be seen at the moment when landscape painting, because of its assumed non-mimetic character, replaced portrait painting as the "highest" form of painting. This process is clearly noticeable in Early Romantic theory, whereas the aesthetics of transcendental idealism continued to maintain the superiority of the human form.[1] The interaction of poetry and philosophy (especially transcendental idealism) was so intense that it is difficult to demarcate a borderline between the two. Novalis said:

The poem of reason is philosophy -- this is the highest claim that reason gives to itself, the unity of reason and imagination. Without philosophy, the human being remains discordant in his essential powers; there are two human beings -- one reasonable being and the other a poet. Without philosophy, imperfect poet -- without poetry, imperfect thinker, critic.[2]

The so-called historical sciences in the sense of literary history, art history, history of law, of religion, etc., received their decisive stimulus during the Romantic period, and even the natural sciences ("Naturphilosophie") were conducted with a Romantic tinge.

How far all of this affected the "entire culture" and what this culture actually consists of is hard to ascertain. The study of an interaction of Romanticism with its surrounding institutions is probably the safest ground for critical study. The salt-mine, the law, the madhouse, the university, and the museum all come to mind and have indeed been made the subjects of detailed investi-/pp. 7-8/ gations.[3] The interaction with the University of Jena appears to be of special importance in this context because Jena was the seat of Early Romanticism and both Schlegels held professorships at this institution. August Wilhelm Schlegel delivered his lectures on Philosophy of Art at Jena University as early as 1798 . But whether these activities affected the general cultural life of the time remains unclear. As soon as one turns to the broader reading public and its literary journals, the reaction against the new discourse is one of unheard hostility and outrage and actually led to a silencing of this group and its Athenaeum in 1800, that is, hardly more than four years after collaborative "symphilosophizing" had come into existence. Special targets of attack were the issues that for us form the core of the Early Romantic discourse, namely, irony, historicity, the union of philosophy and poetry, feminism, the theory of incomprehensibility, the fragment, aestheticism and pure poetry, and so on. The unusually large number of pamphlets and polemical writings against the Early Romantics shows how 
well the challenge to tradition was perceived and how strongly the proposed change was rejected.[4] Goethe and Hegel indicate that this rejection extended to leading intellectuals of that time. Goethe condensed his attitude in the dictum: "The Classical I call the healthy and the Romantic the sick."[5] Hegel called the Early Romantic form of subjectivity the "highest mutiny of the spirit against itself."[6] Toward the end of the nineteenth century, Rudolf Haym considered the unyielding battle against Romanticism that with "passion and hatred" had animated the entire century as a bad dream and thought with relief that now it appeared to be over.[7]

I have also chosen Early Romanticism as an example of humanistic discourse because it is the first major decided pursuit in Germany to break through the traditions of Western humanism and to establish a link with Asian thought and literature, especially Sanskrit literature. In the concluding sections of his On the Language and Philosophy of India (1808), Friedrich Schlegel paid tribute to the great philologists of the fifteenth and sixteenth centuries of the Renaissance "who revived the study of Greek and Eastern literature" and thereby demonstrated how the achievements of different times and regions could intervene in one's own time and engender new accomplishments.[8] He wrote in this instance:

As in popular history, the Asians and Europeans form only one great family and Asia and Europe one indivisible body, we ought to contemplate the literature of all civilized peoples as the progressive development of one entire system, or as a single perfect structure. All prejudiced and narrow ideas will then unconsciously disappear, many points will first become intelligible in their general connection, and every feature thus viewed will appear in a new light.[9]

The first reaction against this expansion of the humanistic discourse and its cultural canon was hostile, however, because it appeared to weaken the Greek origins of the Western tradition and its cultural identity. Goethe argued from the point of view of artistic taste and his predilection for the human form against what he consi- dered to be "Calcutta nightmares" of transitions into the subhuman and suprahuman, whereas Hegel took issue with the logic of Asian thought and claimed it to be so alien to the Western mind that it remained untranslatable. [10] We see Humboldt and A.W. Schlegel on the side of those who defended cross-cultural translation and interaction in this debate. Through Schlegel and Humboldt the disciplines of Asian and Oriental languages and literatures soon obtained chairs at the university and became established fields in academic life.

Whereas these and other institutional and disciplinary aspects of Romanticism became part of the cultural life of the nineteenth century, the critical theory or the philosophy or the humanistic discourse of Early Romanticism remained a matter of contention for a long time and was perhaps not recognized in all its radicalness until very recently. These long spaces between the first articulation of a discourse and its later reception and realization are what is meant by the terms of the contemporary and the posthumous. They do not of course imply a final message or an end result in our relationship to the tradition, but constitute a process without end. This 
ever new approach and reinterpretation of the tradition is another aspect of humanistic discourse formation that will not be pursued here, however.

3. I should like to illustrate the space between the first articulation and later reception or interpretation of humanistic discourses with yet another example, this time taken from Nietzsche's theory of language. When Nietzsche articulated his theory of language first in On Truth and Lie in an Extra-Moral Sense (1873) and later in other aphorisms, almost no attention was paid to this aspect of his writing. Fritz Mauthner, the Austrian writer, himself a prominent language theorist of the time, saw an immediate link between the critique of language and the critique of knowledge in Nietzsche's theory, in that his critique of morality, for instance, proceeded primarily via a critical analysis and dissolution of the traditional designations for "good" and "evil." Yet the result of all this was according to Mauthner only a "new superstition of words," the attitude of a "trumpeter of immorality," of a "moralist" who only wanted to set up "new tablets" and thereby manifested a new belief in language.[11] Later interpretations, when they turned to Nietzsche's theory of language at all, tended to interpret his view of language as relating to prior, more originary principles such as grammar, reason, instinctual moves in the primordial selfpreservation of the human being, to "atavisms," and ultimately to physiological conditions. Nietzsche himself seemed to suggest such an interpretative scheme and often expressed it in his texts. In Aphorism 20 of Beyond Good and Evil, for instance, he wrote: "the spell of certain grammatical functions is ultimately also the spell of physiological valuations and racial conditions." More sophisticated views of Nietzsche's treatment of language as developed, for instance, by Foucault in the realm of communication and indirect communication[12] are lacking in earlier Nietzsche interpretation. Nietzsche's statements on language seemed to require a basic text for the human being, a text in which instinctual drives, cruelty, and survival techniques are the main features. Aphorism 230 of Beyond Good and Evil clearly points in this direction. The task is to rediscover beneath all "flattering colors and make-up" the "frightful prototext homo natura," which means: "To translate man back into nature; to become master over the many vain and overly enthusiastic interpretations and connotations that have so far been scrawled and painted over that eternal basic text of homo natura." It was precisely Nietzsche's theory of language which in more recent interpretations led to a different view of his writing that insisted on the ambiguity of his statements and the impossibility of ascribing a definitive meaning to them. The discovery of the importance of rhetoric for the formation of Nietzsche's philosophical discourse was the main stimulus for this turn. This was primarily accomplished by LacoueLabarthe, who focused on Nietzsche's lectures on rhetoric, and Paul de Man, who extended this new approach to The Birth of Tragedy and other Nietzsche texts.[13] Today, for many of us, Nietzsche's various utterances on language and communication appear to derive from a plurality of voices, of texts, and to configure to that type of complex, ambiguous text constituting the peculiar character of his philosophical or humanistic discourse.

These reorientations in the interpretations of the Early Romantic and Nietzschean discourses did not occur without affecting the context in which they took place. The opposing position is no longer a strong Hegelianism of 
"absolute knowledge" and "comprehended history," but the softer model of hermeneutic truth and dialogical understanding in the style of Gadamer or the "consensus philosophy" of Habermas. According to Habermas, contemporary philosophy no longer expects "unconditional validity or 'ultimate foundations, '" but works with "fallible consciousness" and truth claims at the same time. That is, philosophy has adjusted to the likelihood that its theories will have to be revised: "It prefers a combination of strong propositions with weak status claims; this is so little totalitarian that there is no call for a totalizing critique of reason against it."[14] Such a stance is of course not only the effect of Early Romanticism and Nietzsche, but owes a great deal to the so-called Franco-German debate, another potentially interesting example for the study of spaces between humanistic discourses of today.

4. In conclusion, I should like to offer a few reflections on these issues which mostly move around the fourth question of the last memorandum, i.e., whether humanistic discourse is a necessary ingredient of culture. My examples are meant to indicate that the intellectual model for conceiving of this relationship is not one that can be described in terms of ongoing continuity, enlargement of context, progressive connection, prevailing relation, gradual integration, and emerging totality. The view of the relationship indicated by such terms appears to be too greatly determined by a meaningful collaboration, even if meaning is obscured in the past, does not fully occur in the present, and will not attain self-presence in the future. But the idea of a congruity and interrelationship among the historical phenomena and strata of culture is maintained as operative in spite of all failures and disruptions in particular instances. The relationship between humanistic discourse and its cultural milieu is perhaps better described in terms of challenge , confrontation, disruption, and fragmentation of coherence and congruity, also as far as the institutions and especially the "educational institutions" are concerned. The Early Romantics and Nietzsche seem to indicate this sufficiently. I am inclined to accept as an axiom what Curtius said only with regard to Nietzsche, namely, that true, genuine humanism hardly stands in harmony and a cooperative relationship with the culture and the institutions of its time.[15]

This view does not preclude, but even calls for investigations into the sociocultural field in which artistic, literary, and theoretical works were originally produced. They are certainly "necessary ingredients of culture," as long as one does not construe culture as a substratum of unmediated facts and instead main tains a textualist attitude toward historical reality. But enough and perhaps too much has been said on this subject already. [16]

With regard to the East Asian component in Western humanistic discourses, some of the authors whom I have offered for a discussion appear to be of particular significance, especially F. Schlegel, Nietzsche, and Heidegger. There are few humanists in the Western tradition who enjoy comparable recognition in East Asian thought.[17] I am inclined to assume that this has also to do with the structure of their philosophical or humanistic discourse, especially with features such as the interaction of philosophy and poetry, double reflection, irony, and essayistic, aphoristic, or fragmentary form. 
One final comment concerns the function of the International Center for Humanistic Discourse. I believe to have sufficiently evidenced my skepticism toward an institutionalization of fluid, oscillating, and ungraspable phenomena such as humanism and humanistic discourse. A self-critical view of our function as a Center will in my opinion be a primary task of this group.

\section{Ernst Behler \\ Comparative Literature \\ University of Washington \\ ebehler@U.Washington,edu}

\section{Surface Page d'Acceuil/Home Page}

[1]See A.W. Schlegel, "Die Gemälde. Gespräch," Athenäum 2 (1799): 39-151; and F.W.J. Schelling, The Philosophy of Art, trans. Douglas W. Scott (University of Minnesota Press, 1989): 146.

[2]Novalis Schriften, ed. Richard Samuel, Vol. 3 (Stuttgart, 1968): 531.

[3]Theodore Ziolkowski, German Romanticism and its Institutions (Princeton University Press, 1990).

[4]See Die ästhetische Prügeley. Streitschriften der romantischen Bewegung, ed. Rainer Schmitz (Göttingen, 1992).

[5]In Maxims and Reflections, No. 863.

[6]Hegel's Phenomenology of Spirit, trans. A.W. Miller (Oxford University Press, 1977): 406.

[7]Rudolf Haym, Die romantische Schule (Berlin, 1906): 3.

[8]Friedrich Schlegel, On the Language and Philosophy of the Indians, in: The Aesthetic and Miscellaneous Works of Friedrich von Schlegel, trans. E.T. Millington (London, 1900): 522.

[9]On the Language and Philosophy of the Indians, 526.

[10]Hegel in his review of "Über die unter dem Namen Bhagavad-Gita bekannte Episode des Mahabharata. Von Wilhelm von Humboldt," Werke 11 (Frankfurt, 1986): 131-204. See Kurt Mueller-Vollmer, "Von der Durchdringbarkeit des wirkungsgeschichtlichen Bewußtseins, " Literary Theory and Criticism.. Festschrift in Honor of René Wellek, ed. Joseph P. Strelka, Vol. 1 (New York, 1984): 482-489; and Antoine Berman, The Experience of the Foreign: Culture and Translation in Romantic Germany (Suny Press, 1992).

[11]Fritz Mauthner, Beiträge zu einer Kritik der Sprache, 3 Vols. (Leipzig, 1901-02), Vol. 1, 366-369. 
[12]Michel Foucault, The Order of Things: An Archaeology of the Human Sciences (New York, 1970): 303-307.

[13]Philippe Lacoue-Labarthe, "Le détour (Nietzsche et la rhétorique)," Poétique 5 (1971), 53-76; Paul de Man, "Rhetoric of Tropes (Nietzsche)" and "Genesis and Genealogy (Nietzsche)," Allegories of Reading (New Haven/ London, 1976).

[14]Jürgen Habermas, The Philosophical Discourse of Modernity: Twelve Lectures, trans. Frederick Lawrence (The MIT Press, 1987): 408-409.

[15]Ernst Robert Curtius, "Humanismus als Initiative (1932)," Humanismus, ed. Hans Oppermann (Darmstadt, 1970): 166-189.

[16]See in particular Hayden White "New Historicism: A Comment" and Stanley Fish "The Young and the Restless," both in The New Historicism, ed. H. Aram Veeser (New York), 1989): 293-302 and 303-316.

[17]See in particular René Gérard, L'Orient et la pensée romantique allemande (Paris, 1963); Nietzsche and Asian Thought, ed. Graham Parkes (The University of Chicago Press, 1991); Heidegger and Asian Thought, ed. Graham Parkes (University of Hawaii Press, 1987). 